\title{
Impact of agricultural pollution on the economic environment of Nigeria: The way out
}

\author{
Okojie, Oamhen Manson ${ }^{1 *}$, Osajiele, Mike Aigbe ${ }^{1}$ and Oboniye, Juliana Atabhujena ${ }^{2}$ \\ 1Department of Vocational Education, College of Education, Igueben, Edo State, Nigeria. \\ ${ }^{2}$ Department of Social Sciences, College of Education, Igueben, Edo State, Nigeria. \\ ${ }^{*}$ Corresponding author. Email: anthonyoyase@gmail.com; Tel: +234 9060256604.
}

Copyright (@) 2019 Okojie et al. This article remains permanently open access under the terms of the Creative Commons Attribution License 4.0, which permits unrestricted use, distribution, and reproduction in any medium, provided the original work is properly cited.

Received 5th August, 2019; Accepted 30th August, 2019

\begin{abstract}
Man's effort to provide food, shelter and other basic needs for the increasing human population have resulted in environmental consequences such as agricultural pollution. However, enough understanding of its impact has not been gained by the farmers to be able to address the problems. This paper therefore x-rayed the impact of agricultural pollution on the economic environment; reduction of soil flora and fauna, eutrophication, biomagnifications, rapid oxidation of mineral elements, global warming, blocking of water ways, health challenges, destruction of crops and farm animals, war and conflict, soil erosion and reduction of soil water, nutrients and air transmissions amongst others. Recommendations were consequently made to include laws and regulations that will strictly protect the economic environment, the use of biopesticide, herbicides zero tillage and environmental awareness to the rural population with low literacy level. Meeting the food needs of an ever-increasing global population is difficult but countries must meet the growing food needs while alleviating the effect on agricultural production on land-based ecosystem.
\end{abstract}

Keywords: Agricultural, awareness, community, environment.

\section{INTRODUCTION}

Agricultural pollution is one of the critical problems confronting farmers in Nigeria, but adequate awareness of agricultural pollution had not been gained by the farming communities. Man's effort to provide food, cloth, shelter and other basic needs for the everincreasing human population have resulted in environmental consequences such as agricultural pollution. The exploitation of the natural resources for his own use seems to alter the natural balance in such an extent that, most places in the environment are not fit for agricultural cultivation and even human habitation. In many developing countries of the world, continuous cultivation with inappropriate farming practices have resulted in severe depletion of nutrients and soil organic matter content. It causes soil acidification and soil physical degradation, which consequently lead to increase in the use of fertilizers and soil erosion. The use of fertilizers and other chemicals have fundamentally upset the chemistry of the entire soil. The use of fertilizer has more than doubled the flow of nitrogen and phosphorus compounds in the environment, resulting in a wide spread of water pollution and land degradation. Jande (2005) observed that unrestricted use of pesticide, insecticides, herbicides and indiscriminate dumping of refuse, excreta and animal dungs as well as spillage from refineries and large scale bush burning among others pollute the economic environment.

However, there are obvious arguments in favour of using chemicals in food production. Use of fertilizers have helped to ameliorate low inherent fertility of soils in the tropics. Agbede (2010) obtained increase values of soil organic carbon, total nitrogen, available phosphorus exchangeable potassium, calcium and magnesium in Nigeria. In addition, chemical weed control has in some cases virtually eliminated hand hoeing and even cultivation. Pesticide has protected food from pest damages as it moves from the farm through processing and marketing channels to the dinner table. To move from yields common in subsistence agriculture to those dictated 
by today's food requirements demands dramatic increases in supplies of fertilizers nutrients and other agrochemicals. It is obvious that the knowledge of modern technologies of soil and crop management will offer some potentials for alleviating contaminating of the economic environment by agricultural pollutants. Doitchinova et al. (2017) stated that the agricultural sector can reduce the negative impact of agriculture on the environment through diversification of production, good agricultural research, better resource utilization, crop rotation, soil quality improvement and soil erosion reduction technologies among others.

Tisdale et al. (2006) stated that, land managers must adopt the technologies that, maintain, enhance or protect the productive capacities of our soil resources to ensure future food and fibre supply. This demands that stakeholders in the farm production business should also be involved in fighting the war against agricultural pollution, regrettably enough understanding of its causes and impact have not been gained by the famers. This paper therefore, projects the impact and probable solution of agricultural pollution. Specifically, it identifies:

1. Concepts of agricultural pollution and environment.

2. The sources of agricultural pollution.

3. The impact of agricultural pollution on the economic environment of Nigeria and.

4. Makes recommendations for the control of agricultural pollution.

\section{CONCEPT OF AGRICULTURAL POLLUTION}

Agricultural pollution is the contamination, degradation of the environment and hindrances to agricultural production through natural processes or farming activities with the consequences of injury to human and attendance economic interest. However, the definition from the United States Environment Protection Agency (2013) states that agricultural pollution refers to the biotic or abiotic byproduct of farming practices that result from contamination or degradation of the environment which cause injury to human and their economic interest.

\section{CONCEPT OF ENVIRONMENT}

Different scholars give different definitions of environment. Traditionally, environment is the totality of surrounding that includes natural and biological resources (Godson-ibeji and Chikaire, 2016). "Environment" means what surrounds us. Environment is the natural and social conditions surrounding mankind (World Bank, 2001). Miller (1975) perceived environment as the total external conditions that influences the life of an individual or population, specifically the life of man and other living things on the earth surfaces. In this paper, consequently, economic environment means all the natural and social conditions on which Nigeria economic activities thrive.

\section{NEED FOR INCREASE IN FOOD PRODUCTION}

The continuous increasing human population increases the need for food to survive. Consequently, food security is a major challenge in Nigeria. In the mid-2008, African population was estimated to be 967 million with about 400 million below the age of 15 years. This youthful population structure has momentum for continued growth with annual growth rate of 24 percent and the continent is to reach 1.9 billion by the year 2050 . To prevent malnutrition and the attendant problem, there should be serious effort to increase food production (African Population Data Sheets, 2008).

\section{The economic gain in food production}

Adequate food supply eradicates poverty and malnutrition. Countries with very high level of poverty and malnutrition face limitation of human capital development which is required for sustainable growth (Upton, 2007). When there is abundant food supply among other favourable factors, economic growth will be sustained. If food supply fails to meet with demand then prices will rise. This will have effect on workers' wages and subsequently affect industrial profits, investment and overall economic growth and development in the society.

Food production generates substantial foreign exchange from the export of food item in Nigeria but the productivity issue must be addressed. There is the need to structure the food production sector to attract the elite and younger generation of investors into agriculture.

Establishment of food processing industries in rural areas is helping to bring about the socio-economic transformation which is essential for accelerating rural development. Agriculture helps to overcome unemployment and under employment problems in Nigeria. About $70 \%$ of the working population are employed in agricultural farm work (UKESSAY, 2013).

Nyle (1978) stated that the greatest benefit from the use of pesticide has been the million human lives saved from yellow fever, elephantiasis, malaria and other insect borne diseases, protection of crop and livestock have also brought economic benefits to the society, chemical weed control has virtually eliminated hand hoeing and even cultivation. In the United States pesticides have been a prime factor in the agricultural revolution which makes it possible for less than 6 percent of the population to feed the other $94 \%$. However, there are obvious arguments against the use of chemicals in food production, that, the use of inorganic fertilizers and other chemicals usually lead to decline in soil organic matter content, soil acidification and soil physical degradation which consequently lead to increase in soil erosion. The use of industry fertilizer and other chemicals have fundamentally upset the chemistry of the entire soil. 


\section{THE IMPACT OF AGRICULTURAL POLLUTION ON THE ECONOMIC ENVIRONMENT}

This includes the challenges that are caused in the economic environment through bad farming activities among others:

\section{Reduction of soil flora and fauna}

The use of pesticide to control pests has detrimental effects on organisms other than the target pests: soil flora and fauna. This problem is compounded by the tendency of the chemical to build up in organism as they move up the food chain (Shukla and Chandel, 2006; Nyle, 1978). The extent to which the pesticides and herbicides persist, depends on the compound unique chemistry which affects sorption dynamics and the resulting fate and transport in the soil (USEPA, 2013).

\section{Reduction in agricultural export}

Pollution in Nigeria has resulted in huge loss in agricultural sector which has reduced the economic growth. Although, control of pollution may help to increase the economic growth but once an area has been polluted, it is very hard to control and return the area to its previous state. According to the World Bank record, the sector still accounts for over 26.8 percent of GDP and two third of employment but Nigeria is no longer a major exporter of cocoa, cotton, groundnuts, rubber (Araoye et al., 2018)

\section{Eutrophication}

Excess application of soluble nitrogenous and phosphatic fertilizer may be leached into ground water or carried into river water and cause eutrophication Nitrate $\left(\mathrm{NO}_{3}\right)$ in drinking water causes methaeglobinemia in babies (blue bodies) a situation whereby nitrate in infant stomach is converted to nitrite $\left(\mathrm{NO}_{2}\right)$ which reacts with haemoglobin to form methoemoglobin (Gullan and Cranston, 2010).

\section{Biomagnification}

Heavy metals: Mercury is often added to the soil through fertilizer application, and lead through airborne from automobile. These heavy metals gradually accumulate in the environment and through biomagnifications. They enter the food chain and attain toxic level in human tissue (Nyle, 1978; Wu, 2004).

\section{Effect on soil chemical properties}

Soretire et al. (2011) reported that heavy metals increase the soil $\mathrm{pH}$, organic carbon content and nitrogen mineralization in some pots while reduction occur in others.
Microbial population significantly increased with lead $(\mathrm{Pb})$ and Zinc (Zn) contamination at eight weeks after contamination. This is similar to the observation made by some authors (Doelman and Haanstral, 1984; Hirokui, 1992).

\section{Global warming}

Bush burning and soil tillage cause rapid oxidation of mineral elements in the soil. Consequently, greenhouse gases including nitrous oxide are released into the free atmospheres. This increases global warming through their absorption of heat from solar radiation (MacKenzie et al., 1998). Nuga and Akinbola (2011) physically observed that annual bush burning, quarrying, farming on steep slope are not best management practices for the landscape in south eastern region of Nigeria. It leads to soil erosion which subsequently becomes major contributor to nonpoint pollution in the hydrology of the area. Harisfina and Zornitsa (2018) reported that the highest level of pollution from agricultural sector is by methane, ammonia and carbon dioxide. Ammonia in the atmosphere emits by agricultural activities was $83 \%$ of total agricultural air pollution in 2015. The decomposition of manure under anaerobic condition results in methane $\left(\mathrm{CH}_{4}\right)$ and Nitrate $\left(\mathrm{NO}_{2}\right)$ emission that participate in the global warming.

\section{Blocking water ways and soil erosion}

The transport capacity of ditches, streams, rivers and navigation channels is decreased by soil sedimentation. It also limits the amount of light penetrating the water which affect aquatic lives. The feeding habit of fishes is affected by turbidity from sedimentation. It also affects accumulation of pollutants including phosphorus and various pesticides consequently affecting population dynamics (Shukla and Chandel, 2006). Biswas and Mukherjee (2006) stated that wind erosion is one of the serious problems which adversely affect the productivity of agricultural land and zones through removal of the fertile top soil. It severely reduces the survival and growth of seedlings, blows soil deposit on crops and lower the marketability of leafy vegetable among others. The blown soil increases susceptibility of plants to certain diseases besides transporting some of the pathogens. The dust load in the atmosphere obscures visibility and causes automobile accidents.

\section{Health challenges}

Farm animal wastes amount to 2 billion tons annually, about two third are concentrated in large animal feed lots or other confined animal production units where thousands of animals are reared. Runoff from these animal production units are high in biodegradable organic matter and nitrates. It has been implicated in fish kills and it is a source of nitrate pollution of streams and rivers (Nyle, 
1978). Faecal waste also cause serious problem such as odour. Health problems arise from their role in serving as breeding ground for pathogens. Organic wastes may also contain contaminants including pharmaceutical and personal care product. Each of these products has unique chemistry in terrestrial and aquatic environments as such not all have been assessed for their effects on soil, air and water (USEPA, 2013).

\section{Destruction of crops and fishes}

Oil spills occur both on land and offshore. On land, oil spills destroy crops and damage the quality and productivity of soil that community use for farming. On water, they kill fish and contaminate water used for drinking and other domestic purpose (Amnesty International, 2009). Obioma (2005) conducted a study that investigated agricultural production decline in Ogba-Egbem area of River State. The results of his investigation showed that insects gathered to enjoy the warmth and light of gas flare from the forest at night. The rapid increase in the insect population and their attendant destruction of crops was a new phenomenon that had come with the oil production area (Gbadegesin, 2009).

\section{Destruction of properties}

Fire from bush burning which is usually associated with shifting cultivation causes destruction of both the farmers house and farm, consequently, the farmers are left in poverty and acute want. Children in such locality are also denied access to school, churches and other places of importance (Evelyn and Tyav, 2012).

\section{Contamination of air}

Fertilizer, pesticides, coal burning and waste treatment among others release poisonous substances into the environment. These substances are taken up from air, water and soil. Pollutants from the atmosphere include: Sulphur (IV) Oxide $\left(\mathrm{SO}_{2}\right)$, Hafnieum (HF), hydrogen chloride $(\mathrm{HCL})$, Ozone $\left(\mathrm{O}_{3}\right)$ and carbon (IV) Oxide $\left(\mathrm{CO}_{2}\right)$ among others. Plant growing in water are severely affected by toxic chemicals such as cyanides, chlorine, hypochloride, phenol, benzyl derivatives and heavy metals from sewage. High concentration of these substances causes severe and visible symptoms in plants; chlorosis, discoloration, necrotic lesions, decrease in photosynthesis, stimulation of respiration, changes in cell permeability, disturbances in cell osmotic balance and low fertility (Shukla and Chandel, 2006).

\section{Deforestation}

Forest resources are been removed at alarming rate to create new agricultural line. This practice leads frequency of flooding and land degradation. Example is forest clearing in various parts of Nigeria especially during planting season. Deforestation removes the natural protection of the soil against soil erosion, excess temperature and also upsets nutrient cycle. The practice usually increases rainfall intensity and also the magnitude and frequency of flooding. The deliberate removal of the forest for whatever purpose removes all the economic importance of the forest. The forest has protective value, economic value, medicinal value and it is a source of protein, food, timber and employment (Okojie et al., 2018). Major environmental witness in the agrarian sector are related to deforestation; destruction of natural plants resources, fragmentation of natural habitats, use of fertilizer and pesticides, excessive grazing and drainage among others (Harizanova, 2015, Murkherjee, 2007)

\section{Reduction of air, water and nutrient transmission}

Livestock farming which is commonly practiced in the northern and north central region of Nigeria has a major polluting impact on the soil environment. Water, nutrient and air transmission in the soil are impeded as a result of trampling and the resultant compaction of the soil by cattle. This gives rise to accelerated erosion (Brady, 1978).

\section{CONCLUSION}

This review has shown that agricultural pollution has detrimental impact on the economic environment; reduction of soil flora and fauna, eutrophication, biomagnifications, global warming, blocking of water ways, health challenges, deforestation and contamination of the air environmental among others. Consequently, all the stakeholders in the farming business should adopt environment friendly practices that are recommended in this review to make the environment sustainable.

\section{Recommendations}

1. Farmers should use biopesticides because they are safe to handle and have fewer environmental effects.

2. Laws and regulation to protect the economic environment should be made and strictly implemented.

3. Farmers should use herbicide zero tillage.

4. The government should create environmental awareness for the farmers through the radio, television, religion leader, churches, mosque and institution of learning.

5. Rural education should be handled with seriousness by the government.

6. Farmers should consult with agricultural scientist on the use of agro chemicals.

7. Farmers should compost solid animal waste into manure far from human dwelling places. 
8. Farmers should avoid bush burning when possible to reduce the emission of green house gases into the environment.

9. Scientist should develop applicable safety standard for the use of agro chemicals.

10. Farmers should practice solid erosion control measures.

11. Farmers should practice soil drainage when necessary to avoid the emission of green house gases that may be produced during anaerobic respiration of soil micro organisms

\section{CONFLICT OF INTEREST}

The authors declare no conflict of interest.

\section{REFERENCES}

African Population Data Sheets (2008). Population reference bureau. African Population and Health Research Center. Shelter Afrique Center, Longonot Road, Upper Hill, Nairobi, Kenya

Agbede, T. M. (2010). Tillage and fertilizer effects on some soil properties, leaf nutrient concentrations, growth and sweet potato yield on an Alfisol in southwestern Nigeria. Soil and Tillage Research, 110(1), 25-32.

Amnesty International (2009). Nigeria petroleum, pollution and poverty in Niger Delta. p. 27.

Araoye, F. E., Ajayi, E. O., Olatunji, T. E., \& Aruwaji, A. M. (2018). Environmental Cost Accounting: Effect of Pollution on Economic Growth in Nigeria. Journal of Accounting and Financial Management, 4(1), 20-27.

Biswas, T. O., \& Mukherjee, S. K. (2006). A Textbook of soil science. New Delhi: Tata Megracio Company Limited. Pp.340365.

Brady, N. C. (1978). The nature and properties of soils. New York. Macmillan publishers. Pp. 220-217.

Godson-ibeji, C. C., \& Chikaire, J. U. (2016). Consequences of Environmental pollution on agricultural productivity in developing countries: A case of Nigeria. International Journal of Agricultural and Food Research, 5(3), 1-12.

Doelman, P., \& Haanstra, L. (1984). Short-term and long-term effects of cadmium, chromium, copper, nickel, lead and zinc on soil microbial respiration in relation to abiotic soil factors. Plant and Soil, 79(3), 317-327.

Doitchinova, J., Harizanova, H., \& Stoyanova, Z. (2017). 17 Structural changes and agri-environmental assessment of agriculture in Bulgaria ${ }^{1}$. Risk in the food economy-theory and practice. Pp. 231-243.

UKESSAY (2013). Role of agriculture to economic growth and development economics essay. Retrieved 23-7-2015 from https://www.ukessays.com/essays/economics/role-ofagriculture-to-economic-growth-and-development-economicsessay.php.

Evelyn, M. I., \& Tyav, T. T. (2012). Environmental pollution in Nigeria: The need for awareness creation for sustainable development. Journal of Research in Forestry, Wildlife and Environment, 4(2), 92-105.

Gbadegesin, A (2009). The Impact of oil exploration and production activates on the environment: Implication for peasant agriculture. Seminar paper on oil and environment organised by Fredrick Ebert Foundation in Port Harcourt. p. 78.
Gullan, P. J., \& Cranston, P. S. (2010). The insects: An outline of entomology. UK: Blackwell Publishing. p. 584.

Harisfina, H. B., \& Zornitsa, S. (2018). Impart of agriculture on oil pollution. A paper presented at the international conference on innovations in science and education. March 21-23, 2018, Progue Czech Republic.

Harizanova, H. (2015). State and perspectives for development of agricultural structures in the grain sector. Sofia: ATL publishing.

Hiroki, M. (1992). Effects of heavy metal contamination on soil microbial population. Soil Science and Plant Nutrition, 38(1), 141-147.

Jande, G. G. (2005). Legal mechanisms for the control of pollution on the high sea. African Journal of Environmental law and Development Studies 1(1), 1-13.

$\mathrm{Wu}$, L. (2004). Review of 15 years of research on ecotoxicology and remediation of land contaminated by agricultural drainage sediment rich in selenium. Ecotoxicology and Environmental Safety, 57(3), 257-269.

MacKenzie, A. F., Fan, M. X., \& Cadrin, F. (1998). Nitrous oxide emission in three years as affected by tillage, corn-soybeanalfalfa rotations, and nitrogen fertilization. Journal of environmental quality, 27(3), 698-703.

Miller, G. J. (1976). Living in the environment: Concepts, problems and alternative. California. Wad South Publishing Company Inc.

Mukherjee, N. (2017). Alternative perspectives on livelihoods, agriculture and air pollution: Agriculture in urban and periurban areas in a developing country. Routledge. 234 pages.

Nuga, B. O., \& Akinbola, G. E. (2011). Land use/land cover change detection in Ikwuano area, Abia State Nigeria using landsat data. Nigerian Journal of Soil Science, 21(2), 61-68.

Nyle, B. (1978). The nature and properties of soils New York. Macmillan Publishers. Pp. 551-562.

Obioma, B. K. (2005). An equity into lack of investment in agriculture by the oil communities: The case of Oguta/Egbema and Oguta Communities. Seminar on energy, University of Port Harcourt, Port Harcourt.

Okojie, O. M., Isitekhale, H. I., \& Osayomwanbor, M. I. (2018). A focus on agricultural pollution. Journal of Business and Vocational Education, 1(7), 10-18.

Shukla, R., \& Chandel, R. S. (2006). Plant ecology including ethnobotany and soil science. New Delhi. Chand and company. Pp. 517-526.

Soretire, A. A., Adesodun, J. K., \& Oludemi, B. M. (2011). Effect of the heavy metal contamination of microbial population organic carbon and nitrogen mineralization in soil planted to Legume. Nigerian Journal of Soil Science, 21(2) 112-117.

Tisdale, S. I., James, D. B., Halving, J., \& Werner, L. N. (2006). Soil fertility and fertilizers. Indina Pretice Hall. Pp. 362-526.

United State Environmental protection Agency (USEPA) (2013). Risk management evaluation for concentrate animal feeding operation: U.S EPA National Risk Management Laboratory.

Upton, M. C. (2007). The economics of food production. Ciba Foundation symposium, 177, 61-71.

World Bank (2001). Environmental assessment source books. World Bank Technical Paper. Washington, DC. p. 139. 